\title{
Utilization of Used-Goods as an Environmental Aesthetics Tourist Attraction Case Study: Kampong Pelangi, Semarang
}

\author{
Ratih Dian Saraswati \\ Soegijapranata Catholic University \\ rd_saraswati@unika.ac.id
}

\author{
Peter Ardhianto \\ Soegijapranata Catholic University \\ peter.ardhianto@unika.ac.id
}

\begin{abstract}
Used-goods or scraps do not only pollute the environment but also damage the aesthetics of the environment visually. Handling those scraps wrongly could cause the environment be a slum area. In contrary, by handling those scraps in a good way could not only avoid the diseases but also could upgrade the quality of the environment. One of the examples is what Kampong Pelangi society has done to their environment. Kampong Pelangi which is now a unique tourist spot in the city of Semarang has succeeded to recycle used-goods (reuse) to be the products that not only be used but also be elements of aesthetics enhancement in the village area. Because of those reasons, we are attracted to write of this research paper. The research method is qualitative study with observation approach, interview, and literature study. The expecting results of the discussion are the identification of used-goods that are used by Kampong Pelangi society. Thus, those recycled-goods become part of the visual aesthetics which become one of elements of tourism in Kampong Pelangi.
\end{abstract}

Keywords: used-goods, Kampong Pelangi, aesthetic, environmental, reuse

\section{INTRODUCTION}

\section{Starting from Kampong Gunung Brintik to Become Kampong Pelangi (Rainbow Village)}

Kampong Gunung Brintik located on Brintik Mountain was originally a slum that was full of wild plants and red brick walls that had not been plastered. It is located right on the edge of Kali Semarang, consisting of approximately 325 houses. At first it was known as the village of Semarang's thugs because many newcomers who did not have jobs became thugs and settled illegally there. This Kampong Brintik is located in Kalisari Village, in the city centre of Semarang. Its located behind Pasar Kembang (Florist Market) which sells flower and garden plants.

Topography of Kampong Brintik is hilly and it has 232 houses that now have been painted in colours. The idea of making Kampong Brintik into a village that has an attractive face came from Mr. Slamet Widodo, a school principal in the village. In order to avoid the village being increasingly slum, Pak Slamet Widodo invited the residents to discuss together with the City Government. The idea expressed was to colour the village into a colourful village. The government approved and provided two billion fund subsidies.

As a result, at this time Kampong Brintik transformed into a village that had an attractive, colourful village, and even became a trendsetter of changing the face of the village that inspired the faces of other villages in the city of Semarang. This change certainly makes the village not only a tourist attraction for tourists inside and outside the city, adding to the quality of the village, but also can add economic activity to the village community itself. Kampong Brintik now is known as Kampong Pelangi (Rainbow Village) (pic.1).

Another interesting thing is the voluntary involvement of residents from the beginning of planning to its sustainability. At the beginning, as a trigger for creative steps, the local university made a design on the front face of the village and a design and motif emerged as well as pictures which were the fruit of the ideas of the community / population in the village.

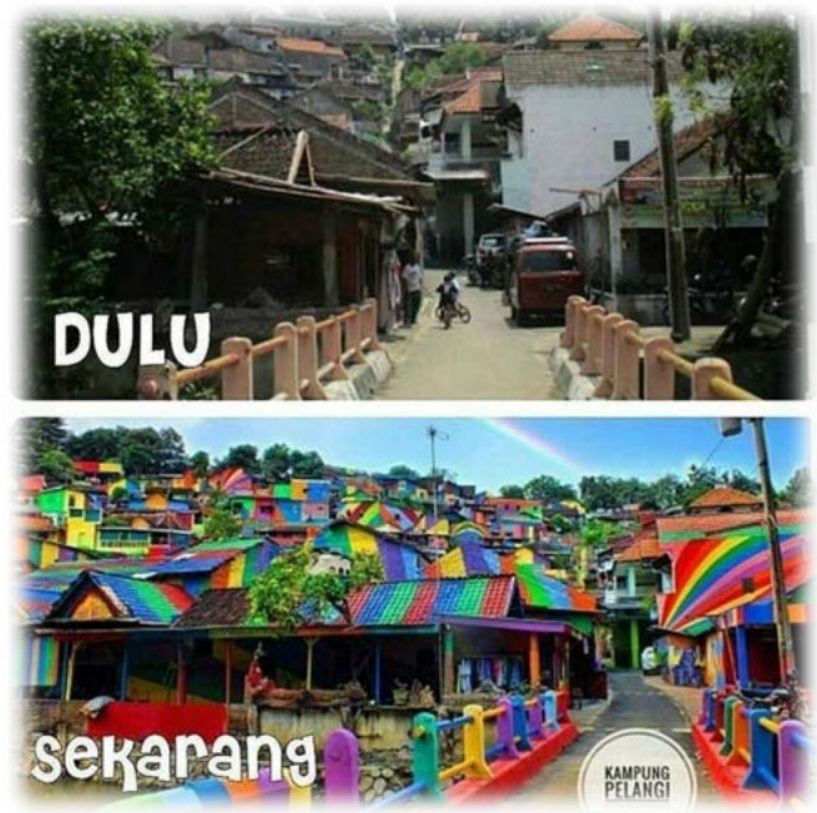

Figure. 1: Kampong Brintik Then and Now

Source: https//adit220393.blogspot.com/201706/kampung-pelangiwonosari-semarang.html, accessed on August 2018

\section{Utilization of Used-Goods as Decorative Elements that Have Functions}

Another form of residents' involvement is the effort to reduce inorganic wastes. They turn the wastes into used-goods that can be reused. According to the results of interviews with several residents, the use of usedgoods is the result of the initiative of residents to add aesthetic value to their home environment which is also a complementary element of the village. 
The use of used-goods is processed as an element which can attract the attention of visitors to take pictures. Waste that is reused into used-goods includes plastic waste bottles, water pipes, wood and newspapers.(pic.2) Some of these used items become elements that not only beautify the appearance of Kampong or the facade of the house but also have a function. The results of the

reprocessing of the used goods also adorn each entrance hall from Kampong Pelangi.(pic.3)

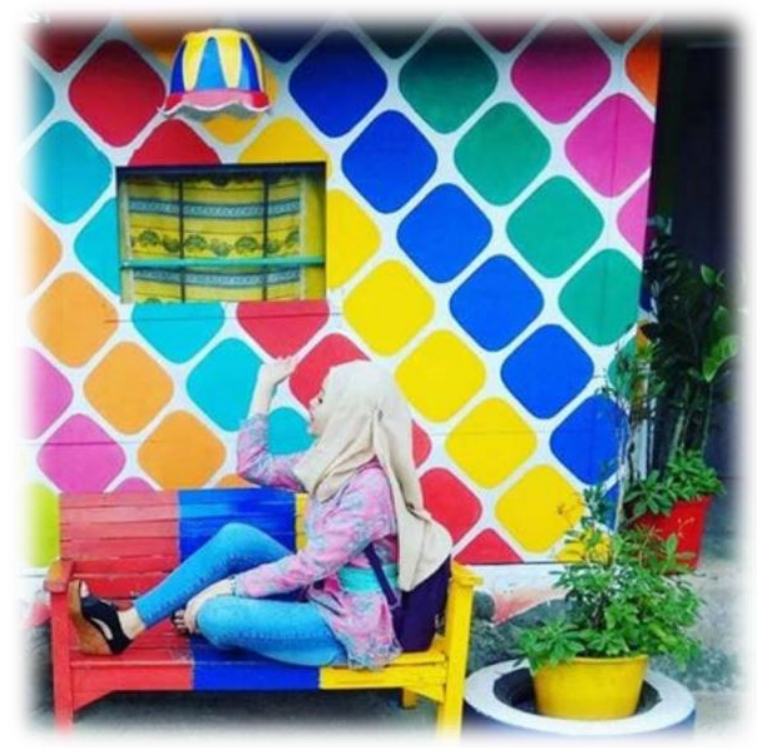

Figure. 2: A tourist taking a selfie in front of a house Source: https//www.hipwee.comtravellagi-ngehits-dimedia-internasional-kampung-pelangi-di-jawatengahmendadak-terkenal-kaya-apa-sih-bentuknyacommentpage-4, accessed on August 2018

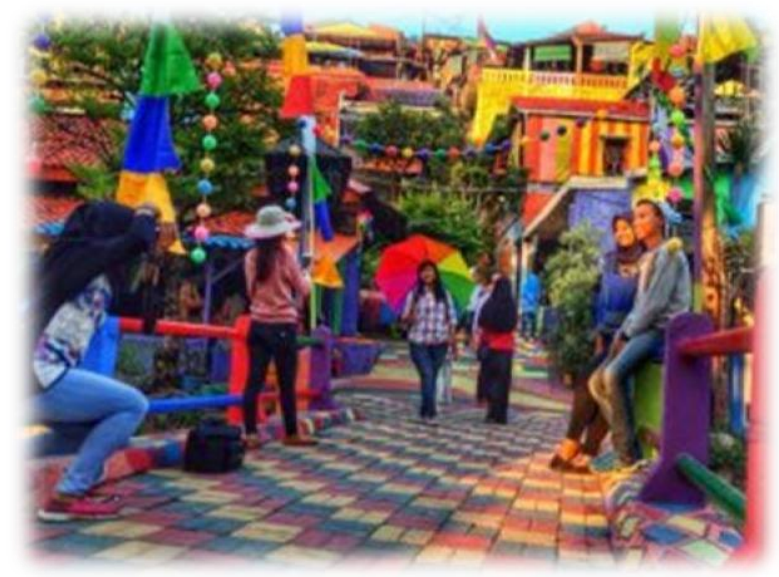

Figure. 3: Entrance of Kampong Source: http//asatu.id20170607/kampung-pelangi-tempatngabuburit-baru-di-semarang, accessed on August 2018

\section{LITERATURE REVIEW}

Management of household waste using the $3 R$ principle (reduce, reuse, and recycle) is simply one of the solutions that can prevent environmental pollution due to poor final waste management.

Understanding 3R (Reduce, Reuse, Recycle) is contained in the Elucidation of Article 11 Paragraph (1) letters $\mathrm{a}, \mathrm{b}$ and $\mathrm{c}$ of Government Regulation Number 81 of 2012 concerning Household Waste Management and Household-like Waste. What is meant by restrictions on waste generation (Reduce) according to the Elucidation of Article 11 Paragraph (1) letter a Government Regulation Number 81 of 2012 concerning Household Waste Management and Garbage Similar to Household Waste is an effort to minimize waste generation carried out before a product is produced and / or product packaging until the end of product use and / or product packaging.

Waste Reuse according to the Elucidation of Article 11 Paragraph (1) letter c Government Regulation Number 81 of 2012 concerning Household Waste Management and Waste Similar to Household Waste is an attempt to reuse waste in accordance with the same function or different functions and / or reuse parts of waste that are still useful without going through a process of processing first. Reuse is an activity to reuse materials or materials that are still suitable for use, such as using a handkerchief instead of tissue, reusing used mineral bottles for flower pots or using used sauce bottles for cooking oil containers.

According to Berge in his book The Ecology of Building Materials (2000), there are three hierarchical levels of recycling according to the benefits obtained, namely:

1. Re-use

Re-use or reuse is the highest level in recycling, which is to reuse the items that have been used but still have the remaining age.

2. Recycle

Recycle requires energy and process to make used materials into materials that are suitable for use.

\section{Energy Recovery}

Energy recovery is the lowest level in recycling. All materials that are impossible to use are burned to obtain potential energy that is still present in the material through the combustion process.

The essence of the purpose of recycling is to extend the useful life of an object or material. The longer the period of use of building materials or the possibility to be reused, the smaller the possibility of building materials causing waste and debris that pollute the environment.

\section{METHODOLOGY}

The research method used is a qualitative descriptive research method. Research conducted by means of collecting data qualitatively through observation and documentation of the case study which is strengthened by user interviews. Primary data was obtained through literature studies on the concept of recycling using the reuse method.

\section{DISCUSSION}

Based on the results of field observations, documentation and thus be discussed, it was found that used-goods used by residents to add aesthetic value to Kampong Pelangi can be categorized into four basic elements. The four elements are wood, plastic, used newspapers and iron pipes. 
Each element of used goods is reused and transformed into elements that have different functions from the initial function and have aesthetic value. Not only change the shape of the used goods, the residents try to create simple things and colour them.

Table. 1: Result and Discussions

Source: Personal Analysis

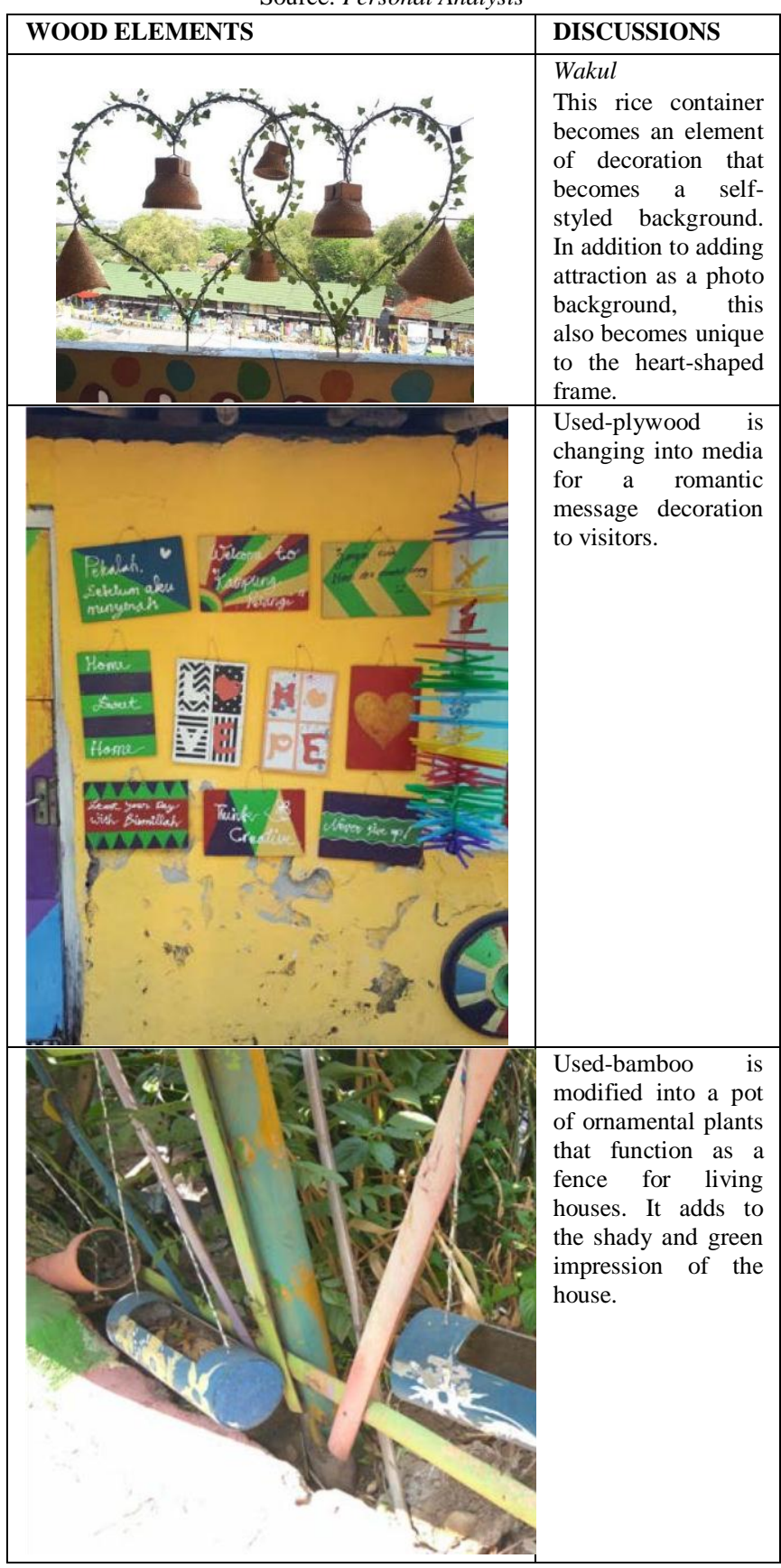

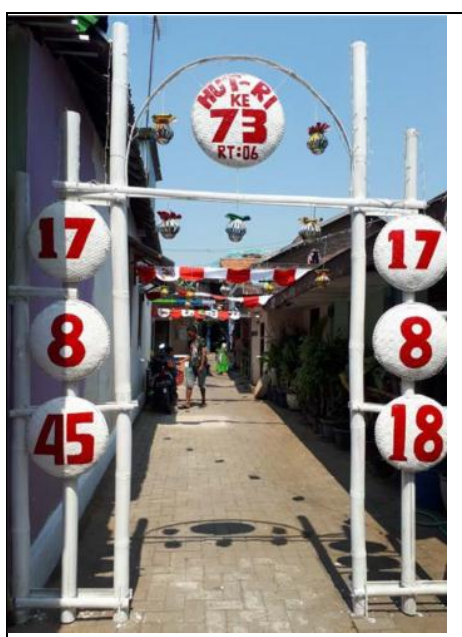

Tembir

The original tray used to separate whole rice and broken rice is now changed by the people of Kampung Pelangi as part of the alley's gate as well as 73 years of information on Indonesia's independence and information on independence dates in 1945 and 2018.
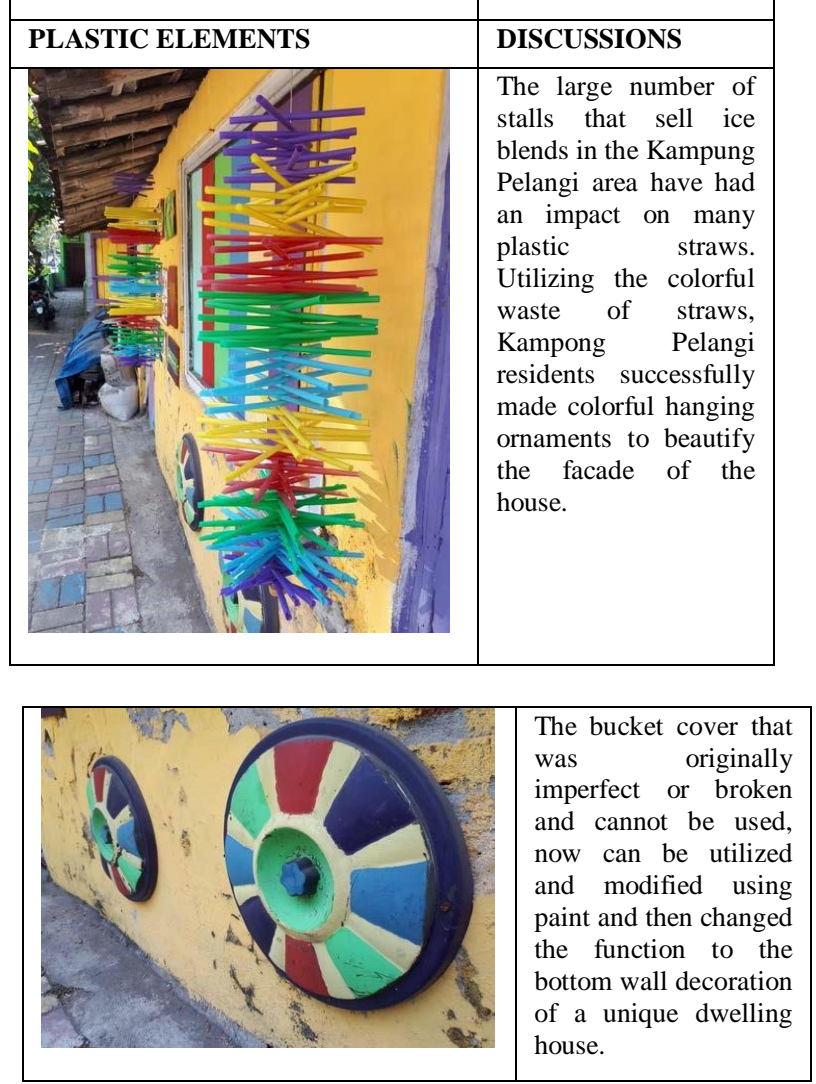

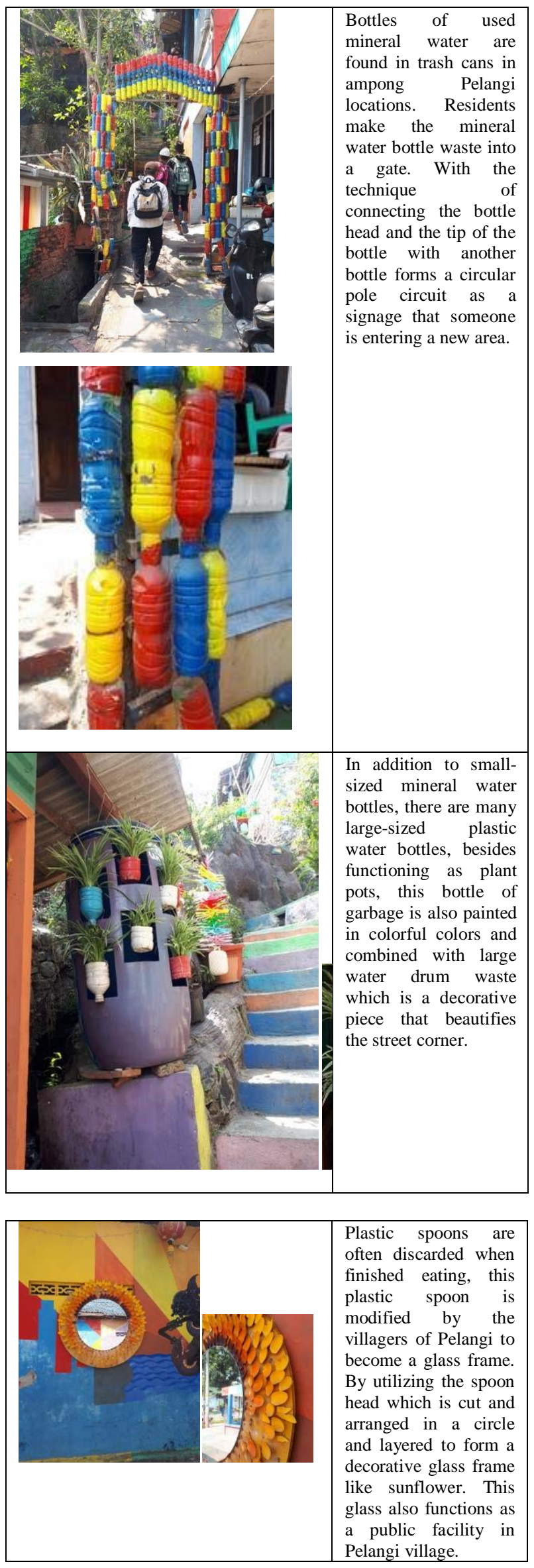
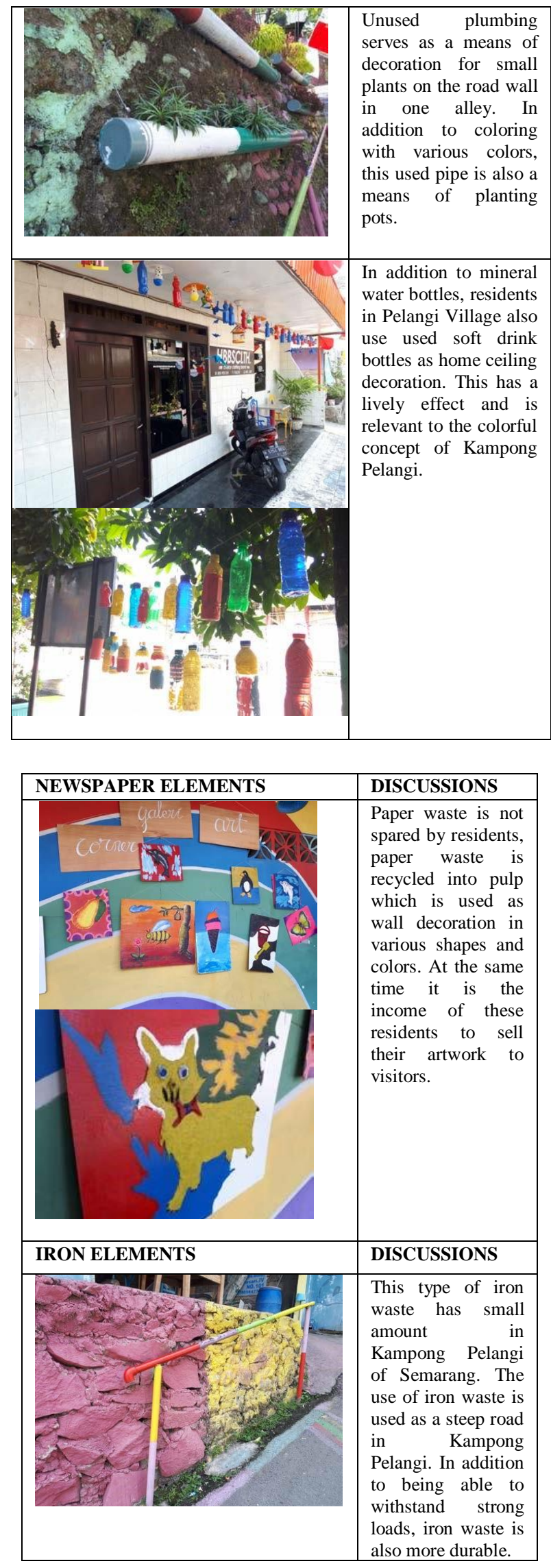

\section{CONCLUSION}

Reuse is an efficient solution in Kampong Pelangi. Almost all of the alleys found in Kampong Pelangi utilize waste. Used-goods that are used or recycled are iron, plastic, wood and paper. The recycling concept 
serves to break down the waste and beautify the location of Kampong Pelangi which is frequented by the public after raising a colorful theme. Besides being used for other functions. Recycling of used goods in Kampung Pelangi also has a positive impact and its own uniqueness in branding destinations. The recycling initiative originated from the residents themselves who have economic limitations to decorate the village.

\section{REFERENCES}

Peraturan Pemerintah Nomor 81 Tahun 2012 Tentang Pengelolaan Sampah Rumah Tangga Dan Sampah Sejenis Sampah Rumah Tangga Bjorn Berge." The Ecology of Building Materials." 2000.

Mr. Heri. 2018. Interview "The Residents Involment in Improving The Quality of Kampong Pelangi" on Gang IV, Kampong Pelangi, Semarang.
Mrs. Joni. 2018. Interview "The Residents Involment in Celebration Indonesian Independence” on Gang II, Kampong Pelangi, Semarang.

Mr. To. 2018. Interview "The Residents Involment in Making a Handicraft from Used-Goods" on Gang II, Kampong Pelangi, Semarang. https//adit220393.blogspot.com/201706/kampungpelangi-wonosari-semarang.html, accessed on August 2018.

https//www.hipwee.comtravellagi-ngehits-di-mediainternasional-kampung-pelangi-di-jawatengahmendadak-terkenal-kaya-apa-sihbentuknyacomment-page-4, accessed on August 2018. http//astu.id/20170607/kampung-pelangi-tempatngabuburit-baru-di-semarang, accessed on August 2018. 